\title{
PENGARUH SELF EFFICACY TERHADAP PRESTASI BELAJAR MATEMATIKA SISWA SD DALAM PEMBELAJARAN DARING
}

\author{
Pramesthi Ningrum ${ }^{1 *}$, Rina Dyah Rahmawati ${ }^{2}$ \\ 1,2 Universitas PGRI, Yogyakarta, Indonesia. \\ *Corresponding Author: @ pramestyningrum19@gmail.com
}

\begin{tabular}{l} 
Info Artikel \\
\hline Sejarah Artikel: \\
Diterima: 28/11/2021 \\
Direvisi : 01/12/2021 \\
Disetujui: 07/12/2021 \\
\hline Keywords: \\
Self Efficacy, Mathematics \\
Learning Achievement, \\
Online Learning \\
\hline
\end{tabular}

Kata Kunci:

Self Efficacy, Prestasi Belajar Matematika,

Pembelajaran Daring

\begin{abstract}
Recently, education has been faced with learning that is not only carried out offline but also carried out online. Online learning has even been implemented since elementary education. This of course affects student learning outcomes. This study aims to determine the effect of self-efficacy on elementary students' mathematics learning achievement in online learning. This study used a quantitative survey method and was carried out on fourth grade elementary school students in Cluster II, Pleret Bantul District, consisting of 5 schools located in the sub-district area. The population in this study was 203 students and a sample of 132 students, with the technique used in sampling is proportional random sampling. Data collection techniques used are questionnaires and documentation. While the data analysis technique in this study used simple regression analysis with the help of SPSS 24.0. The results of the study concluded that there was a positive and significant influence between self-efficacy on elementary mathematics learning achievement in online learning. Data analysis resulted in a t-count value of 5.785 with a significance of 0.000 , it was obtained $t$-table $=1.978$ which can be seen from $t$ count $>$ t table $=5.785>1.978$ and a significance value of $0.000<0.05$.
\end{abstract}

Abstrak. Beberapa waktu terakhir ini pendidikan dihadapkan pada pembelajaran yang tidak hanya dilaksanakan dengan luring tetapi juga dilaksanakan secara daring. Pembelajaran daring bahkan dilaksanakan sejak dari pendidikan dasar. Hal ini tentu saja berpengaruh terhadap hasil belajar siswa. Penelitian ini bertujuan untuk mengetahui pengaruh self efficacy terhadap prestasi belajar matematika siswa SD dalam pembelajaran daring. Penelitian ini menggunakan metode kuantitatif survey dan dilaksanakan pada siswa SD Kelas IV di Gugus II Kecamatan Pleret Bantul, terdiri dari 5 sekolah yang terdapat dalam wilayah kecamatan tersebut. Populasi dalam penelitian ini adalah 203 siswa dan sampel sebanyak 132 siswa, dengan teknik yang digunakan dalam pengambilan sampel adalah proporsional random sampling. Teknik pengumpulan data yang digunakan adalah angket dan dokumentasi. Sedangkan teknik analisis data pada penelitian ini menggunakan analisis regresi sederhana dengan bantuan SPSS 24.0 Hasil penelitian menyimpulkan bahwa terdapat pengaruh positif dan signifikan antara self efficacy terhadap prestasi belajar matematika SD dalam pembelajaran daring. Analisis data menghasilkan nilai harga $t$ hitung sebesar 5.785 dengan signifikansi 0,000 , maka didapatkan $\mathrm{t}$ tabel $=1.978$ dimana dapat dilihat dari $\mathrm{t}$ hitung $>\mathrm{t}$ tabel $=5.785>1.978 \mathrm{dan}$ nilai signifikansi $0,000<0,05$.

How to Cite: Ningrum, P., \& Rahmawati, R.D. (2022). PENGARUH SELF EFFICACY TERHADAP PRESTASI BELAJAR MATEMATIKA SISWA SD DALAM PEMBELAJARAN DARING. Prima Magistra: Jurnal Ilmiah Kependidikan, 3(1), 41-47. https://doi.org/10.37478/jpm.v3i1.1394

Alamat korespondensi:

FKIP Universitas PGRI Yogyakarta. Jl. PGRI 1 Sonosewu no. 117 PO BOX 1123. Yogyakarta 55182

@pramestyningrum19@gmail.com
Penerbit:

Program Studi PGSD Universitas Flores.

(\$) primagistrauniflor@gmail.com 


\section{PENDAHULUAN}

Indonesia pada awal Maret 2020 digemparkan dengan adanya wabah penyakit yang berasal dari Tiongkok. Penyakit tersebut merupakan penyakit COVID-19, penyakit menular yang diakibatkan oleh infeksi virus. Penyakit ini bisa ditularkan lewat kontak fisik sentuhan ataupun berjabat tangan dengan pengidap dan memegang wajah, hidung, serta mulut oleh tangan yang terpapar virus Corona.

Penyebaran virus tersebut menyebabkan banyak kerugian dalam segala aspek bidang kesehatan, perekonomian, politik, social budaya, keagamaan, dan pendidikan. Bidang pendidikan di Indonesia menjadi dampak adanya virus tersebut. Pemerintah membuat kebijakan dalam pelaksanaan kegiatan belajar mengajar. Peserta didik tetap memperoleh layanan pembelajaran selama COVID- 19 lewat penyelenggaraan belajar dari rumah yang sesuai dengan surat edaran pemerintah tentang pelaksanaan kebijakan pembelajaran dalam masa darurat penyebaran COVID- 19. Peraturan yang telah dikeluarkan pemerintah tidak mengurangi tanggungjawab guru yang tetap harus mendidik dan mengajar siswa. Pembelajaran daring merupakan salah satu solusi yang digunakan oleh guru untuk tetap mengajar dan mendidik peserta didik walaupun tidak bertatap muka secara langsung. Pembelajaran daring dilakukan oleh guru melalui beberapa platform diantaranya zoom, google meet, google classroom, google form, whatsapp group dan sebagainya.

Pembelajaran daring adalah sistem pendidikan yang dilakukan dengan tidak bertatap muka langsung, namun menggunakan platform yang bisa menunjang proses belajar mengajar (Hendarini \& Wulandari, 2013). Pembelajaran daring merupakan salah satu metode yang digunakan untuk memutus mata rantai penyebaran COVID- 19. Pembelajaran daring juga tidak melibatkan peserta didik berkerumun. Semangat siswa pada proses pembelajaran daring saat ini dipengaruhi oleh beberapa faktor. Faktor tersebut adalah faktor eksternal dan faktor internal. Faktor eksternal merupakan faktor yang berasal dari luar peserta didik, misalnya berasal dari lingkungan, baik lingkungan sosial maupun lingkungan non sosial. Sedangkan faktor internal merupakan faktor yang berasal dari dalam diri peserta didik tersebut termasuk didalamnya self efficacy atau efikasi diri.

Efikasi diri adalah evaluasi diri, apakah bisa melaksanakan kegiatan yang baik ataupun kurang baik, tepat ataupun salah, mampu ataupun tidak mampu mengerjakan sesuatu sesuai yang dipersyaratkan (Sukmawati et al., 2013). Sedangkan menurut Wulandari (2013) efikasi diri adalah keyakinan diri seseorang pada kemampuannya untuk meraih tujuan tertentu. Berdasarkan penjelasan tersebut dapat disimpulkan bahwa efikasi diri adalah keyakinan diri untuk dapat menyelesaikan pekerjaan yang sudah ditentukan. Efikasi diri dapat menentukan keberhasilan maupun kegagalan dalam belajarnya. Ketika peserta didik mengalami keberhasilan dalam belajarnya maka efikasi dirinya akan meningkat dan tingginya efikasi diri akan memotivasi seseorang secara kognitif untuk dapat bertindak lebih giat. Pembelajaran daring saat ini dapat berjalan dengan lancar apabila siswa memiliki self efficacy atau kemampuankemampuan untuk menggerakkan motivasi, kemampuan kognitif dan tindakan-tindakan yang diperlukan untuk memenuhi tuntutan situasi. Self efficacy memiliki peran penting untuk menentukan keberhasilan peserta didik dalam mengerjakan tugas.

Tinggi rendahnya self efficacy yang ada pada dalam diri siswa akan dapat mempengaruhi setiap aktivitas yang dilakukan. Menurut Santrock (Ruliyanti \& Laksmiati, 2014), siswa yang memiliki tingkat self efficacy tinggi akan lebih mungkin untuk dapat menguasai tugas daripada siswa yang memiliki tingkat self efficacy yang rendah. Selaras dengan pendapat Ormrod dalam Musdalifa (2019) bahwa: "ketika siswa memiliki kemampuan yang sama, siswa yang yakin bisa mengerjakan tugas akan mencapai keberhasilan dibandingkan dengan siswa yang tidak yakin akan sukses dalam tugas yang dikerjakannya."

Keberhasilan yang dicapai oleh siswa terdiri dari beberapa macam, salah satunya yaitu prestasi. Menurut Djamarah (2012) "prestasi merupakan hasil dari suatu kegiatan yang telah dikerjakan, diciptakan, baik secara individual maupun kelompok." Oleh karena 
itu, prestasi merupakan hasil yang tidak akan dapat diperoleh tanpa usaha.

Prestasi erat hubungannya dengan belajar. Menurut Slameto (2013) pandangan seseorang tentang belajar akan mempengaruhi tindakan-tindakannya yang berhubungan dengan belajar dan setiap orang mempunyai pandangan berbeda-beda tentang belajar. Hasil belajar berkaitan dengan ketercapaian dalam memperoleh kemampuan sesuai dengan tujuan yang telah direncanakan sebelumnya (Sanjaya, 2008). Proses belajar mengajar berlangsung siswa akan mengalami banyak perubahan, misalnya dari yang tidak tahu menjadi tahu dan akan mendapatkan pengetahuan yang baru. Oleh karena itu, dapat dikatakan bahwa prestasi belajar adalah hasil yang diperoleh dari proses perubahan dan perilaku yang terjadi pada diri siswa.

Prestasi belajar yang baik merupakan harapan siswa, tidak terkecuali siswa Sekolah Dasar. Karakteristik siswa kelas tinggi salah satunya yaitu memandang nilai sebagai tolak ukur prestasi belajar (Vandini, 2018). Prestasi belajar yang bagus didapatkan oleh siswa perlu melakukan usaha yang sungguh-sungguh. Beberapa usaha yang perlu dilakukan siswa antara lain: belajar dengan tekun, mengikuti pembelajaran dengan sungguh-sungguh, rajin membaca, dan yakin akan kemampuan yang dimiliki.

Berdasarkan hasil studi pendahuluan yang telah dilakukan peneliti di beberapa SD se-Kecamatan Pleret, serta hasil wawancara dengan beberapa guru yang mengajar di SD se-Kecamatan Pleret peneliti memperoleh informasi bahwa terdapat siswa yang telat mengumpulkan tugas saat pembelajaran daring, siswa tidak mengerjakan soal yang sulit. Selain itu masih ada siswa yang kurang memiliki keyakinan diri dalam hal mengerjakan tugas. Hal ini dapat dilihat dari masih adanya siswa yang memilih bertanya kepada orang tuanya daripada berusaha sendiri untuk menyelesaikan soal yang diberikan. Selain dari segi keyakinan diri, kebiasaan belajar siswa juga masih perlu diperbaiki. Terdapat siswa yang tidak memanfaatkan waktu yang mereka miliki dirumah untuk belajar akan tetapi menggunakannya untuk bermain. Siswa yang memiliki nilai rapor kurang memuaskan berasal dari siswa yang kurang percaya diri, kurang antusias dalam pembelajaran daring, dan mengeluh ketika mendapatkan tugas atau pekerjaan rumah dari guru. Jika hal tersebut terus berlanjut akan mempengaruhi prestasi belajar siswa.

Berdasarkan uraian latar belakang permasalahan tersebut, guna mengetahui seberapa besar pengaruh pembelajaran daring terhadap self efficacy perlu dilakukan penelitian tentang "Pengaruh Self Efficacy Terhadap Prestasi Belajar Matematika Siswa SD Dalam Pembelajaran Daring”.

\section{METODE PENELITIAN}

Penelitian ini dilaksanakan pada bulan November - Mei 2021 pada semester genap 2020/2021. Penelitian ini dilaksanakan di kelas IV Sekolah Dasar Gugus II Kecamatan Pleret yang terdiri dari 5 sekolah diantaranya yaitu: SD N Kanggotan, SD N Kauman, SD N Pungkuran, SD N Putren, dan SD NU Pemanahan. Desain penelitian yang digunakan adalah kuantitatif. Populasi pada penelitian ini berjumlah 203 sedangkan teknik pengambilan sampel menggunakan teknik proporsional random sampling. Dalam menentukan besarnya sampel menggunakan tabel Krejcie sehingga diperoleh 132 sampel. Teknik pengumpulan data menggunakan dokumentasi dan angket. Adapun kisi-kisi angket self efficacy sebagai berikut:

Tabel 1. Kisi-kisi Instrumen angket self efficacy

\begin{tabular}{|c|c|c|c|c|}
\hline \multirow{2}{*}{ Komponen } & \multirow[t]{2}{*}{ Indikator } & \multicolumn{2}{|l|}{ No. Item } & \multirow{2}{*}{$\begin{array}{l}\text { Jumlah } \\
\text { Item }\end{array}$} \\
\hline & & $(+)$ & $(-)$ & \\
\hline \multirow[t]{4}{*}{ Magnitude } & Mengerjakan & & & \\
\hline & $\begin{array}{l}\text { tugas yang } \\
\text { sulit }\end{array}$ & 1,3 & 2,7 & 4 \\
\hline & $\begin{array}{l}\text { Mengerjakan } \\
\text { tugas sesuai } \\
\text { kemampuanny } \\
\text { a }\end{array}$ & 6,20 & 4,5 & 4 \\
\hline & $\begin{array}{l}\text { Pantang } \\
\text { menyerah } \\
\text { dalam } \\
\text { menghadapi } \\
\text { kesulitan }\end{array}$ & $8,9,10$ & $\begin{array}{l}12, \\
13\end{array}$ & 5 \\
\hline \multirow[t]{3}{*}{ Strength } & $\begin{array}{l}\text { Kerja keras } \\
\text { atau usaha } \\
\text { maksimal }\end{array}$ & 23,25 & $\begin{array}{l}27, \\
29\end{array}$ & 4 \\
\hline & $\begin{array}{l}\text { Tetap bertahan } \\
\text { pada situasi } \\
\text { yang sulit }\end{array}$ & 17,28 & 24 & 3 \\
\hline & optimisme & 14,16 & 15 , & 4 \\
\hline
\end{tabular}




\begin{tabular}{|c|c|c|c|c|}
\hline & & \multicolumn{3}{|c|}{19} \\
\hline & $\begin{array}{l}\text { Menambah } \\
\text { waktu belajar }\end{array}$ & 26 & 21 & 2 \\
\hline \multirow[t]{3}{*}{ Generality } & $\begin{array}{l}\text { Mampu } \\
\text { mengerjakan } \\
\text { semua } \\
\text { pekerjaan } \\
\text { dalam waktu } \\
\text { yang } \\
\text { bersamaan }\end{array}$ & 11,3 & 18 & 3 \\
\hline & \begin{tabular}{ll}
\multicolumn{2}{l}{ Mengerjakan } \\
tugas pada \\
bidang yang \\
berbeda
\end{tabular} & 22 & & 1 \\
\hline & Jumlah & & & \\
\hline
\end{tabular}

Pada uji coba instrument diperoleh 3 butir soal yang tidak valid dari 30 butir soal seluruhnya. Sedangkan hasil uji reliabilitas diperoleh nilai koefisien alpha Cronbach sebesar 0,919 yang berarti reliabel. Teknik analisis data menggunakan uji normalitas, uji linearitas, dan uji regresi sederhana.

\section{HASIL DAN PEMBAHASAN}

Berdasarkan hasil uji coba instrument yang telah dilaksanakan di SD Jejeran dengan jumlah data 30 siswa $(\mathrm{N}=30)$ dengan taraf signifikansi 5\% maka dapat diketahui $r$ tabel sebesar 0,361. Hasil uji validitas dengan bantuan program SPSS 24.0 menunjukkan bahwa 30 butir yang telah diujikan terdapat 3 butir yang tidak valid atau gugur. Tiga butir tersebut karena rhitung <rtabel yang terdapat pada butir soal nomor 5, 25, dan 29.

Pengujian reliabilitas menggunakan rumus Alpha Cronbach diketahui bahwa nilai Cronbach's Alpha pada variabel self efficacy sebesar 0,919>0,600 dengan jumlah item sebanyak 27 butir. Berdasarkan hasil tersebut disimpulkan bahwa kuesioner variabel self efficacy dapat dikatakan sangat reliabel karena nilai Cronbach's Alpha lebih besar dari 0,600.

Uji prasyarat analisis yang terdiri dari uji normalitas dan uji linearitas. Uji normalitas menggunakan Kolmogorovsmirnov dengan bantuan program SPSS dan diperoleh nilai sebesar 0,055 , most extreme differences positif sebesar 0,035 dengan nilai asymp sig 0,200. Berdasarkan nilai aysmp sig lebih besar dari 0,05 maka dapat disimpulkan bahwa data dari penelitian ini berdistribusi normal. Sedangkan uji linearitas diperoleh nilai Deviation from Linearity $>0,05$ atau 0,097>0,05 maka dapat disimpulkan bahwa terdapat hubungan linier secara signifikan antara variabel self efficacy terhadap variabel prestasi belajar.

Berdasarkan hasil perhitungan yang dilakukan dengan menggunakan analisis regresi sederhana menggunakan bantuan SPSS Statistics 24.0 for windows diketahui bahwa nilai koefisien korelasi (rxly) sebesar 0,452 yang menunjukan bahwa hasil tersebut bernilai positif, berdasarkan hal itu terdapat pengaruh positif dari variabel self efficacy terhadap prestasi belajar matematika SD kelas IV gugus II Kecamatan Pleret Bantul. S elanjutnya hasil dari koefisien determinasi $\left(r^{2} x y\right)$ sebesar 0,205 apabila nilai tersebut diubah ke dalam bentuk persen menjadi 20,5\% dari hasil tersebut bahwa self efficacy dapat menjelaskan $20,5 \%$ terhadap perubahan prestasi belajar dan kemungkinan masih ada $79,5 \%$ faktor lain yang bisa mempengaruhi prestasi belajar siswa yang tidak diteliti oleh peneliti.

Berdasarkan hasil signifikansi hipotesis diperoleh nilai signifikansi sebesar $0,000<$ 0,05 dengan $f_{\text {hitung }}$ sebesar 33.470 . Berdasarkan hasil tersebut dapat disimpulkan bahwa adanya pengaruh positif dan signifikan antara self efficacy terhadap prestasi belajar matematika SD kelas IV Gugus II Kecamatan Pleret Bantul. Berdasarkan hasil tersebut dapat disimpulkan terdapat adanya pengaruh positif dan signifikan self efficacy terhadap prestasi belajar matematika SD kelas IV gugus II Kecamatan Pleret Bantul.

Hasil penelitian menunjukkan terdapat pengaruh positif dan signifikan antara self efficacy terhadap prestasi belajar matematika SD Kelas IV Gugus II Kecamatan Pleret Bantul dibuktikan secara statistic dan diperkuat oleh hasil pengkategorian kelas interval dengan variabel self efficacy (X) dilihat dari besarnya mean $(\mathrm{M})=79,43$ berada pada kelas interval 74,25 $<\mathrm{X} \leq 87,75$ dengan persentase $42,40 \%$ termasuk dalam kategori tinggi dan variabel prestasi belajar (Y) dilihat dari mean (M) Selanjutnya dilihat dari nilai rata-rata (mean) 76,55 yang berada pada kelas interval $74,9<\mathrm{X}$ dengan persentase $54,5 \%$ termasuk dalam kategori sangat tinggi. Berdasarkan uji statistic dan hasil pengkategorian kedua variabel tersebut dapat 
disimpulkan bahwa semakin tinggi self efficacy diikuti oleh peningkatan prestasi belajar matematika.

Salah satu faktor yang mempengaruhi prestasi belajar adalah faktor psikologis. Faktor psikologis yang dapat mempengaruhi prestasi belajar diantaranya self efficacy atau efikasi diri siswa yang masih rendah. Self efficacy adalah keyakinan seseorang dalam mengerjakan sesuatu atau tugas yang telah diberikan guna mencapai tujuan tertentu. Tinggi rendahnya efikasi diri seseorang dapat dilihat dari tiga aspek. Menurut Bandura (1997: 42-43) terdapat 3 aspek efikasi diri yaitu level, strength, dan generality. Salah satu faktor yang mempengaruhi self efficacy bernilai positif lainnya yaitu adanya bimbingan belajar orang tua ketika pembelajaran daring, orang tua yang berpengalaman dalam bidang pendidikan sehingga mampu memberikan motivasi dan bimbingan, adanya pembelajaran yang menggunakan platform zoom yang menjadikan siswa mudah memahami materi ketika dijelaskan langsung oleh guru, dan dibukanya sesi tanya jawab ketika pembelajaran melalui WAG sehingga siswa yang kurang paham terhadap materi yang telah disampaikan bisa bertanya kepada guru.

Media pembelajaran daring yang digunakan pada masing-masing sekolah bervariasi, dalam penelitian ini SD Kanggotan, SD Putren, SD Pungkuran, SD NU Pemanahan menggunakan platform Whats App Group (WAG) sedangkan SD Kauman menggunakan platform Whats App Group (WAG) dan Zoom. Media tersebut digunakan untuk menunjang proses belajar mengajar dalam pembelajaran daring.

Menurut Suhery et al. (2020), pembelajaran daring juga tidak terlepas dari berbagai kekurangan, yaitu sebagai berikut: 1.) Kurangnya interaksi antara pengajar dan siswa atau bahkan antara siswa itu sendiri, bisa memperlambat terbentuknya values dalam proses belajar mengajar; 2.) Kecenderungan mengabaikan aspek akademik atau aspek sosial dan sebaliknya mendorong aspek bisnis atau komersial; 3.) Proses belajar dan mengajarnya cenderung ke arah pelatihan dari pada pendidikan; 4.) Berubahnya peran guru dari yang semula menguasai teknik pembelajaran konvensional, kini dituntut untuk menguasai teknik pembelajaran dengan menggunakan ICT (Information Communication Technology); 5.) Siswa yang tidak mempunyai motivasi belajar yang tinggi cenderung gagal; 6.) Tidak semua tempat tersedia fasilitas internet (berkaitan dengan masalah tersedianya listrik, telepon, dan komputer). Berdasarkan kekurangan pembelajaran daring tersebut, pembelajaran daring saat ini masih berjalan dengan lancar. Kekurangan tersebut bisa dijadikan referensi pada peneliti selanjutnya.

\section{SIMPULAN DAN SARAN}

Berdasarkan hasil penelitian yang dilakukan tentang pengaruh self efficacy terhadap prestasi belajar matematika siswa SD dalam pembelajaran daring ini dapat ditarik kesimpulan terdapat pengaruh yang positif dan signifikan dari variabel self efficacy terhadap prestasi belajar matematika siswa SD kelas IV Gugus II Kecamatan Pleret Bantul. Hal tersebut berarti bahwa semakin tinggi self efficacy yang dimiliki oleh siswa maka semakin tinggi pula prestasi belajarnya, sebaliknya maka semakin rendah self efficacy yang dimiliki oleh siswa maka berpengaruh rendahnya prestasi belajarnya.

Pernyataan tersebut dibuktikan dengan hasil analisis yang telah dilakukan dengan hasil sebesar $20,5 \%$ dengan nilai signifikansi $0,000<0,05$ dengan $f_{\text {hitung }}$ sebesar 5,785. Bagi peneliti selanjutnya diharapkan dapat melakukan penelitian tentang pengaruh self efficacy terhadap variabel-variabel yang lainnya atau data penunjang berdasarkan teori yang digunakan.

\section{DAFTAR PUSTAKA}

Arikunto, S. (2014). Prosedur Penelitian: Suatu Pendekatan Praktik. Jakarta: Rineka Cipta. Google Scholar

Asri, K. Z., Witono, A. H., \& Affandi, L. H. (2020). Pengaruh Ekspektasi Guru dan Self-Efficacy Siswa Terhadap Hasil Belajar Pada Siswa Kelas V di SD Gugus V Cakranegara Tahun Pelajaran 2019/2020. JURNAL ILMIAH PENDAS: PRIMARY
EDUCATION 
JOURNAL, l(1),

19-25. https://doi.org/10.29303/pendas.v1i1.51

Bandura, Albert. (1997). Self Efficacy: The Exercise Of Control. New York : W.H. Freeman and Company. Google Scholar

Danuri, Siti M. (2019). Metode Penelitian Pendidikan. Bantul: Samudra Biru (Anggota IKAPI). Google Scholar

Djamarah, S.B. (2012). Prestasi Belajar dan Kompetensi Guru. Surabaya: Usaha Nasional. Google Scholar

Fransisca, M. (2016). Faktor Internal yang Mempengaruhi Prestasi Belajar Tiga Mahasiswa Angkatan 2013 Program Studi Bimbingan dan Konseling Fakultas Pendidikan dan Bahasa Unika Atma Jaya Jakarta. Psiko Edukasi, 14(1), 1-17. http://ojs.atmajaya.ac.id/index.php/fkip/ article/view/543

Ghufron, M. N., \& Risnawati, R. (2012). Teori-Teori Psikologi Cetakan III. Yogyakarta: Ar-ruzz media. Google Scholar

Handarini, O. I., \& Wulandari, S. S. (2020). Pembelajaran daring sebagai upaya study from home (SFH) selama pandemi covid 19. Jurnal Pendidikan Administrasi Perkantoran (JPAP), 8(3), 496-503.

https://journal.unesa.ac.id/index.php/jpa p/article/view/8503

Haris, R., Wardani, D. K., \& Nugroho, J. A. (2016). PENGARUH EFIKASI DIRI DAN FASILITAS BELAJAR TERHADAPPRESTASI BELAJAR SISWA PROGRAM KEAHLIAN PEMASARAN SMK NEGERI 1 SUKOHARJO TAHUN AJARAN 2015/2016. Jurnal Pendidikan Bisnis dan Ekonomi, 2(2). https://jurnal.fkip.uns.ac.id/index.php/pt n/article/view/9645

Hassankhani, H., Aghdam, A. M., Rahmani, A., \& Mohammadpoorfard, Z. (2014). The relationship between learning motivation and self efficacy among nursing students. Research and Development in Medical
Education, 4(1),

97-101. http://dx.doi.org/10.15171/rdme.2015.01 6

Heruman, H. (2013). Model Pembelajaran Matematika di Sekolah Dasar. Bandung. Remaja Rosdakarya. Google Scholar

Ibrahim, I \& Suparni, S. (2012). Pembelajaran Matematika Teori dan Aplikasinya. Yogyakarta: Suka-Pres. Google Scholar

Janah, A. M. (2020). Pengaruh Metode Crossword Puzzle Terhadap Minat dan Hasil Belajar Aqidah Akhlak Siswa MI Tarbiyatussibyan Tanjung Kalidawir Tulungagung. http://repo.uinsatu.ac.id/id/eprint/14680

Jess Feist \& Gregory J. Feist. (2011). Teori Kepribadian. Jakarta: Salemba Humanika. Google Scholar

Mahmudi, M. H., \& Suroso, S. (2014). "Efikasi diri, dukungan sosial dan penyesuaian diri dalam belajar". Persona: Jurnal Psikologi Indonesia, 3(02). https://doi.org/10.30996/persona.v3i02.3 82

Musdalifa, F. Z. (2019). Pengaruh dukungan sosial teman sebaya dan efikasi diri terhadap prestasi belajar siswa kelas XI IPS SMAN Bandar Kedungmulyo (Doctoral dissertation, Universitas Islam Negeri Maulana Malik Ibrahim). http://etheses.uinmalang.ac.id/id/eprint/16972

Nasution, M. K. (2018). Penggunaan metode pembelajaran dalam peningkatan hasil belajar siswa. Studia Didaktika, 11(01), 9-16. http://www.jurnal.uinbanten.ac.id/index. $\mathrm{php} /$ studiadidaktika/article/view/515

Ningsih, S. (2014). Realistic mathematics education: model alternatif pembelajaran matematika sekolah. Jurnal Pendidikan Matematika, 1(2), 73-94. http://jurnal.uinantasari.ac.id/index.php/jpm/article/view 197 
Prasojo, R. J. (2014). Pengaruh Perhatian Orang Tua Dan Kedisiplinan Belajar Terhadap Prestasi Belajar Mata Pelajaran IPS. Ekonomi IKIP Veteran Semarang, 2(1), 37082. Google Scholar

Prihandoko, (2006) Pemahaman dan Penyajian Konsep Matematika secara benar dan menarik. Jakarta : Dediknas, h. 21. Google Scholar

Rigianti, H. A. (2020). Kendala Pembelajaran Daring Guru Sekolah Dasar Di Banjarnegara. Elementary School: Jurnal Pendidikan dan Pembelajaran ke-SD-an, 7(2). https://doi.org/10.31316/esjurnal.v7i2.7 68

Ruliyanti, B. D., \& Laksmiati, H. (2014). Hubungan antara Self Efficacy dan Self Regulated Learning dengan Prestasi Akademik Matematika Siswa SMAN 2 Bangkalan. Character, 3(2), 1-7. https://ejournal.unesa.ac.id/index.php/ch aracter/article/view/10976

Sadikin, A., \& Hamidah, A. (2020). Pembelajaran Daring di Tengah Wabah Covid-19: (Online Learning in the Middle of the Covid-19 Pandemic). BIODIK, 6(2), 214-224. https://doi.org/10.22437/bio.v6i2.9759

Sanjaya, W. 2008. Perencanaan dan Desain Sistem Pembelajaran. Jakarta: Kencana Prenada Media Grup.

Slameto, S. (2003). Belajar Dan FactorFaktor yang Mempengaruhinya. Jakarta: Rineka Cipta

Sinaga, D. H., \& Kustanti, E. R. (2017). HUBUNGAN ANTARA DUKUNGAN SOSIAL TEMAN SEBAYA DENGAN EFIKASI DIRI WIRAUSAHA PADA MAHASISWA FAKULTAS ILMU SOSIAL DAN ILMU POLITIK UNIVERSITAS

DIPONEGORO. Jurnal EMPATI, 6(1), 74-79. https://ejournal3.undip.ac.id/index.php/e mpati/article/view/15133

Suhery, S., Putra, T., \& Jasmalinda, J. (2020). SOSIALISASI PENGGUNAAN APLIKASI ZOOM MEETING DAN GOOGLE CLASSROOM PADA GURU DI SDN 17 MATA AIR PADANG SELATAN. Jurnal Inovasi Penelitian, 1(3), 129-132. https://doi.org/10.47492/jip.v1i3.90

Sukmawati, N. P. F., Suarni, N. K., \& Renda, N. T. (2013). Hubungan antara efikasi diri dan kebiasaan belajar terhadap prestasi belajar siswa kelas V SDN di Kelurahan Kaliuntu Singaraja. Mimbar $P G S D$ Undiksha, 1(1). https://ejournal.undiksha.ac.id/index.php /JJPGSD/article/view/717

Surya, A. (2018). Learning trajectory pada pembelajaran matematika sekolah dasar (SD). Jurnal Pendidikan Ilmiah, 4(2), 22-26. Google Scholar

Syofian, S. (2015). Statistika Terapan Untuk Perguruan Tinggi. Jakarta: Prenandanedia Group. Google Scholar

Vandini, I. (2016). Peran kepercayaan diri terhadap prestasi belajar matematika siswa. Formatif: Jurnal Ilmiah Pendidikan MIPA, 5(3). http://dx.doi.org/10.30998/formatif.v5i3. 646

Wulandari, S. (2013). Pengaruh Efikasi Diri Terhadap Minat Berwirausaha Pada Siswa Kelas XII Di SMK Negeri Surabaya. Fakultas Ekonomi, Unesa, Kampus Ketintang Surabaya, 1(1), 120. Google Scholar

Wulanningtyas, M. E., \& Ate, H. M. (2020). Pengaruh Efikasi Diri Siswa Terhadap Prestasi Belajar Matematika. KoPeN: Konferensi Pendidikan Nasional, 2(1), 166-169. http://ejurnal.mercubuanayogya.ac.id/index.php/Prosiding_KoPe N/article/view/1095 